\title{
Estimating evapotranspiration in the central mountain region of Veracruz, Mexico
}

\author{
Estimación de la evapotranspiración en la región montañosa central de Veracruz, México
}

\author{
Mónica Ballinas a, Manuel Esperón-Rodríguez a , Víctor L Barradas a* \\ *Corresponding author: ${ }^{a}$ Universidad Nacional Autónoma de México, Instituto de Ecología, \\ Laboratorio de Ecofisiología Tropical, 04510 México, D.F. México, vlbarradas@ecologia.unam.mx
}

\begin{abstract}
SUMMARY
The global, regional and local hydrological cycle is strongly linked to vegetation distribution. The hydrological cycle is composed by precipitation, infiltration, runoff, transpiration and evaporation. Evaporation is influenced by high temperatures, high winds and low relative humidity. This work is focused on the study of evapotranspiration (ET) as the main variable of water loss in the water balance in the central mountain region of Veracruz, Mexico. ET was estimated using the Penman-Monteith model, which requires environmental (net radiation, vapor pressure deficit, air temperature and wind intensity) and physiological (stomatal and canopy resistances and leaf area index) variables. These variables were measured in two sites within the region: La Joya and La Orduña, comparing different ecosystems: pine-oak, pine forests and grassland, and cloud forest and sugarcane crop, respectively. Results show that both, the estimated and real ET, are high; although, we found net surplus related to precipitation at both sites (533.8 and $526.5 \mathrm{~mm})$ from September 2006 to August 2007. Apparently, no water deficits in either location were found; however, in the dry season water gain was very low, zero or negative. March and April were the months presenting the lowest water contribution to the system. The forests in the central mountain region of Veracruz can provide ecosystem services favoring evapotranspiration and regulating water balance, although the lack of information on the magnitude and value of this variable has hindered recognition and understanding of these forests.
\end{abstract}

Key words: net radiation, vapor pressure deficit, canopy resistance, aerodynamic resistance, leaf area index.

\section{RESUMEN}

El ciclo hidrológico global, regional y local está fuertemente ligado a la distribución de la vegetación. El ciclo hidrológico está conformada por la precipitación, la infiltración, la escorrentía, la transpiración y la evaporación. La evaporación se ve influenciada por altas temperaturas, fuertes vientos y baja humedad relativa. Este trabajo se centra en el estudio de la evapotranspiración (ET) como variable principal de la pérdida de agua en el balance hídrico en la región montañosa central de Veracruz, México. La ET se estimó utilizando el modelo de Penman-Monteith, que requiere de variables medioambientales (radiación neta, déficit de presión de vapor, temperatura del aire e intensidad del viento) y fisiológicas (resistencia estomática y del dosel e índice de área foliar). Estas variables se midieron en dos sitios de la región (La Joya y La Orduña), comparando diferentes ecosistemas: bosques nublados de montaña, de pino-encino y pino, y cultivos de caña de azúcar y pastizales. Los resultados muestran que la ET estimada y real fueron altas; aunque se encontró una ganancia neta relacionada con la precipitación en ambos sitios (533,8 y 526,5 mm) desde septiembre de 2006 hasta agosto de 2007. Al parecer, no se encontraron déficits hídricos en ambos lugares; sin embargo, en la estación seca la ganancia de agua fue muy baja, nula o negativa. Marzo y abril fueron los meses con la menor contribución de agua al sistema. Los bosques de la región montañosa central de Veracruz pueden proporcionar servicios ecosistémicos que favorecen la evapotranspiración y regulan el balance hídrico.

Palabras clave: radiación neta, déficit de presión de vapor, resistencia del dosel, resistencia aerodinámica, índice de área foliar.

\section{INTRODUCTION}

The global, regional and local hydrological cycle is strongly linked to vegetation distribution. Availability and distribution of moisture in time and space are factors that determine the structure and floristic composition of natural ecosystems. Survival, competitive ability and growth patterns of the species of plant communities depend on this (Barradas 2000). The hydrological cycle is composed by precipitation, infiltration, runoff, transpiration and evaporation. Evaporation is very significant, as it is favored by the atmosphere surface conditions. The atmosphere capacity to retain humidity is so enormous that nearly three quarters of the water precipitated on the Earth's surface evaporates before it can return to the oceans. Evaporation depends on the demand imposed by the environment, given by high temperatures, high winds and low relative humidity. Evaporative air demand is very important for vegetation due to the influence of precipitation to supply moisture to the soil (Torres et al. 2002).

Using water balance is one way to determine the amount of water that can access to a site or region. Water balan- 
ce analyzes all water inputs and outputs from a given system. One of the most important components of the water balance is evapotranspiration, which refers to the loss of water throughout the plant-soil system. Temperate ecosystems in tropical latitudes have been ignored in terms of studying evapotranspiration; however, different studies indicate qualitative and quantitative differences among sites with different environmental parameters (Williams et al. 1998), and a difference of productivity along a precipitation gradient (Runyon et al. 1994).

For Veracruz, Mexico, the center of the state is a region with a high frequency of fog, playing an important role in water balance. Furthermore, a reduction in precipitation and fog frequency and an increase in the number of consecutive dry days in the region have been reported, probably due to the high deforestation that has been being held in the region for a long time (Barradas et al. 2010, 2011, EsperónRodríguez and Barradas 2014a). These changes also have repercussions on other climatic variables such as solar radiation, which is expected to be more intense where both rainfall and fog frequency decreased (Barradas et al. 2011). However, little information regarding the determination of potential evapotranspiration in the region is known.

In this work we hypothesized that water availability can be determined by estimating the average cumulative rainfall and the evapotranspiration using the PenmanMonteith model. This model depends directly on net radiation and vapor pressure deficit and is inversely proportional to the resistance of the canopy (stomatal resistance) and drag. Our aims were to estimate net radiation and evapotranspiration and to determine the water balance in the central mountain region of Veracruz.

\section{METHODS}

Study area. The central mountain region of Veracruz in eastern Mexico (19 54'08" N, 96057'19" W, figure 1) forms part of Neovolcanic Ridge and Sierra Madre Oriental. Abrupt topography is the main characteristic of the region with a pronounced altitudinal gradient, from the sea level up to $5,500 \mathrm{~m}$ in a distance of $100 \mathrm{~km}$ (Barradas et al. 2010). As a result, climate in this region is made up as follows: 1) complex interactions among the prevailing synoptic systems; 2) mountainous topography; 3) the plantatmosphere interaction, and 4) proximity to the Gulf of Mexico (Barradas et al. 2010).

Average annual temperatures range between 10 and $29{ }^{\circ} \mathrm{C}$, and annual precipitation ranges from 600 to 1,200 $\mathrm{mm}$, with a maximum of $3,000 \mathrm{~mm}$ in wet regions with a $\mathrm{pH}$ from 4.48 to 6.19 . Soils in the region are of volcanic origin or Andisols, with physical characteristics that favor good struc-tural stability. They have low bulk density $\left(0.5 \mathrm{Mg} \mathrm{m}^{-3}\right)$, high porosity with significant micro-porosity, significant amount of water stable micro-aggregates, complexation with organic matter, and stable amounts of iron and aluminum (Meza and Geissert 2003).
Data collection. Data collection was conducted in 2006 and 2007, in different types of vegetation: cloud forest (shade-grown coffee), pine-oak forest and pine forest; sugarcane crop and grassland. The cloud forest and the sugarcane crop are located in La Orduña $\left(19.451944^{\circ} \mathrm{N}\right.$, 96.938056 W, 1,160 m a.s.1. municipality of Coatepec). The pine-oak and pine forests and the grassland are located in La Joya $(19.610833 \mathrm{~N}, 97.027222 \mathrm{~W}, 2,160 \mathrm{~m}$ a.s.1.; municipality of Acajete). The tree species measured were: Alnus acuminata Kunth, Liquidambar styraciflua L., Pinus patula Schl. et Cham, P. ayacahuite Ehren., P. montezumae Lamb., Platanus mexicana Moric., Quercus crassifolia Humb. et Bonpl, Q. germana Schldl. et Cham., Q. laurina Bonpl., Q. microphylla Née and Q. xalapensis Bonpl. The measured crops were Saccharum officinarum L., and Lolium multiflorum Lam.

Net radiation was measured with a net radiometer Rebs type (Q-7.1, Campbell Scientific, Logan, UT, USA). Wind direction and speed were measured with a vane-anemometer (05103, RM Young, Traverse City, MI, USA). Temperature and relative humidity were measured with thermocouples and humidity sensors (HMP35C, Vaisala, Finland) at $2 \mathrm{~m}$ above the canopy. All sensors were connected to a data acquisition system (21X, Campbell Scientific, Logan, UT, USA), which conducted the data every second keeping the average every 20 minutes from 9:00 to 17:00 hours (h, local time) at each site.

Leaf area was estimated by measuring leaf area index (LAI-2000, LI-COR, Lincoln, NE, USA). Measurements of stomatal conductance (1/stomatal resistance) were performed with a gas diffusion porometer (LI-1600, LI-COR, Lincoln, NE, USA) in three leaves from at least two individuals in three different sites. These measurements were performed through the day every hour from 09:00 to 17:00 h.

Data analyses. In this study we analyzed water balance for the central mountain region of Veracruz. Water balance is usually estimated from the equation:

$$
\theta\left(\mathrm{t}+\mathrm{t}_{\mathrm{i}}\right)=\theta(\mathrm{t})+P p-\left(\mathrm{ET}+\mathrm{D}_{\mathrm{R}}+\mathrm{Ro}\right)
$$

where $\theta=$ volumetric water content in the soil used in the interval $\left(\mathrm{t}+\mathrm{t}_{\mathrm{i}}\right), P p=$ precipitation, $\mathrm{ET}=$ evapotranspiration, and $\mathrm{D}_{\mathrm{R}}$ and $\mathrm{Ro}=$ drainage beyond the root zone and runoff, respectively, in $\mathrm{mm}$.

However, simplified water balance $(\mathrm{WB}=P p-\mathrm{ET})$ was used, as drainage and runoff are recoverable whereas evapotranspiration is not (Barradas 2000). Concerning evapotranspiration, this was calculated using the PenmanMonteith model, which has the advantage of using less physical and physiological parameters (Bosveld and Bouten 2001). Evapotranspiration $\left(\mathrm{mm} \mathrm{s}^{-1}\right)$ was calculated by using the equation:

$$
\mathrm{ET}=\left[\Delta \mathrm{Q}_{\mathrm{N}}+\rho \mathrm{Cp}\left(V P D / \mathrm{r}_{\mathrm{A}}\right)\right] / \lambda\left[\Delta+\gamma\left(1+\left(\mathrm{r}_{\mathrm{C}} / \mathrm{r}_{\mathrm{A}}\right)\right)\right][2]
$$




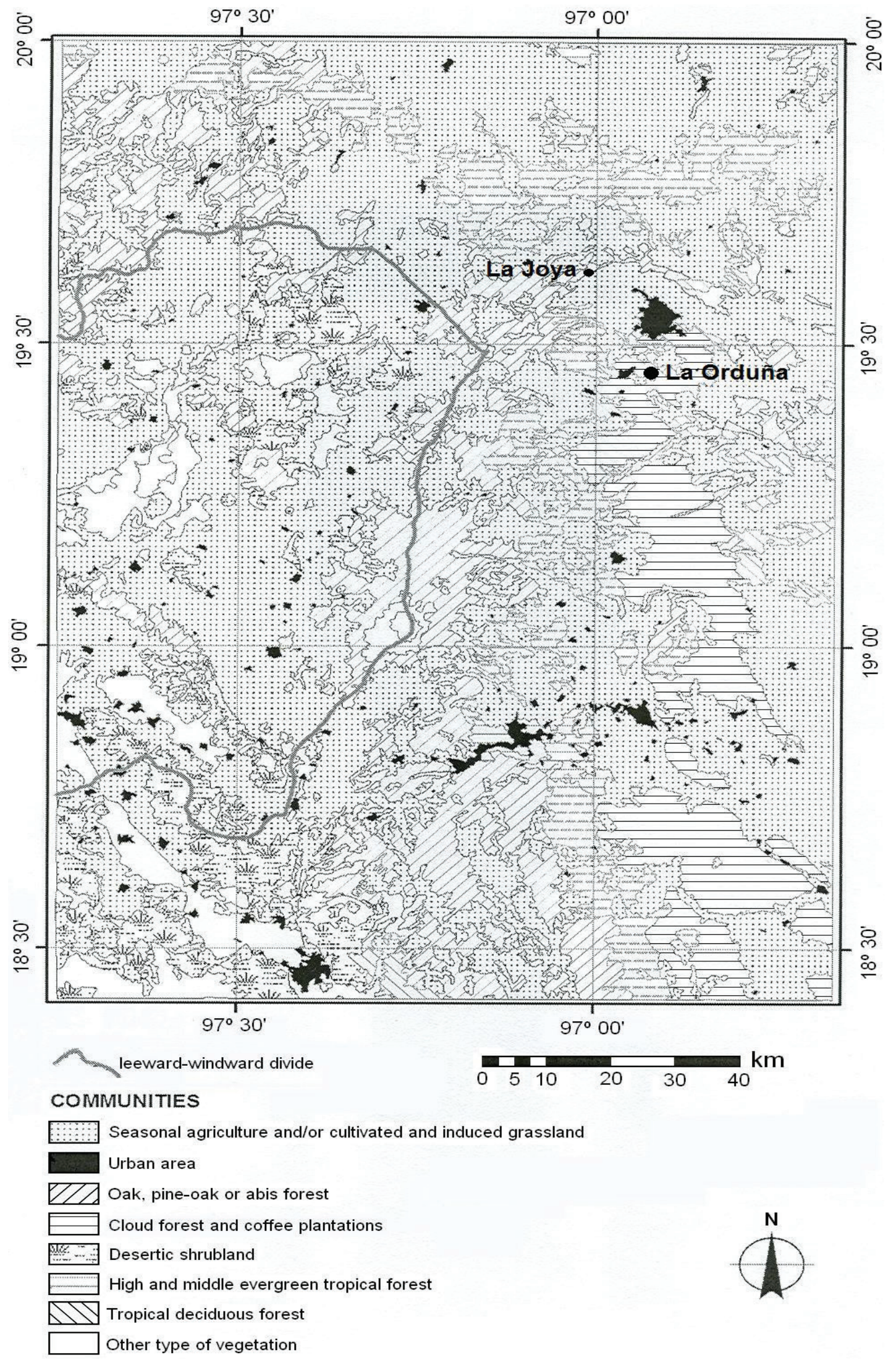

Figure 1. Location of the study site and actual land use comprising cultivation and urban areas.

Localización del sitio de estudio y el uso actual del suelo que comprende las áreas de cultivo y las urbanas. 
where $\lambda=$ latent heat of vaporization $\left(\mathrm{kJ} \mathrm{g}^{-1}\right), \Delta=$ slope of the saturation vapor pressure $\left(\mathrm{kPa}^{\circ} \mathrm{C}^{-1}\right), \mathrm{Q}_{\mathrm{N}}=$ net radiation flux $\left(\mathrm{W} \mathrm{m}^{-2}\right), \rho=$ air density at constant pressure $\left(\mathrm{kg} \mathrm{m}^{-3}\right)$, $\mathrm{Cp}=$ specific heat of air at constant pressure $\left(\mathrm{J} \mathrm{kg}^{-1} \mathrm{~K}^{-1}\right)$, $V P D=$ vapor pressure deficit of the air $(\mathrm{kPa}), \gamma=$ psychrometric constant $\left(\mathrm{kPa} \mathrm{K}^{-1}\right), \mathrm{r}_{\mathrm{C}}=$ canopy resistance $\left(\mathrm{s} \mathrm{m}^{-1}\right)$, and $\mathrm{r}_{\mathrm{A}}=$ aerodynamic resistance $\left(\mathrm{s} \mathrm{m}^{-1}\right)$.

Canopy resistance is a characteristic of each plant surface; it determines the transfer degree of water vapor from the canopy to the atmosphere and is a function of stomatal resistance and leaf area index.

Net radiation $\left(Q_{N}\right)$ can be measured or calculated from the following relationship:

$$
\mathrm{Q}_{\mathrm{N}}=\left[(1-\alpha) \mathrm{R}_{\mathrm{SI}}-(\mathrm{I} \uparrow+\mathrm{I} \downarrow)\right.
$$

where $\mathrm{R}_{\mathrm{S}}, \alpha$, and (I $\left.\uparrow+\mathrm{I} \downarrow\right)$ ) solar radiation reaching the surface, the albedo and the long wave radiation balance, respectively.

Estimation of $\mathrm{R}_{\mathrm{SI}}$ includes the position and slope orientation given by the following equation (Jones 1992):

$$
\mathrm{R}_{\mathrm{SI}}=\tau \mathrm{S}_{0} \cos \Theta
$$

where $\tau=$ transmission coefficient of the atmosphere, $\mathrm{S}_{0}=$ solar constant $\left(1360 \mathrm{~W} \mathrm{~m}^{-2} \approx 2750 \mu \mathrm{mol} \mathrm{m}^{-2} \mathrm{~s}^{-1}\right)$, and $\cos \Theta=[(\operatorname{sen} \phi \cdot \cos \eta)(-\cos \alpha \cdot \operatorname{sen} \chi)-\operatorname{sen} \eta \cdot(\operatorname{sen} \alpha \cdot \operatorname{sen} \chi)$ $+(\cos \phi \cdot \cos \eta) \cdot \cos \chi] \cdot \cos \delta+[\cos \phi \lambda \cdot(\cos \alpha \cdot \operatorname{sen} \chi)+$ $(\operatorname{sen} \phi \cdot \cos \chi] \cdot \operatorname{sen} \delta$

where $\varphi, \eta, \delta, \alpha$ and $\chi$ represent the latitude, angular time of day, day of the year (solar declination), azimuth and slope conditions, respectively, $\delta$ is given by (Jones 1992): $\cos \delta$ $=-23.4\left[360\left(t_{d}+10\right) / 365\right]$ and $t_{d}$ is the day of the year (or Julian day).

The transmission coefficient of the atmosphere has values from 0 to 1 ; atmosphere totally dark and totally clear, respectively, for a relatively clear atmosphere the value 0.8 is used and for a moderately cloudy atmosphere the value of 0.3 is used. The coefficient $\tau$ was calculated using the radiation measurements at the study sites $\left(\mathrm{Q}_{\mathrm{S}}=\mathrm{R}_{\mathrm{SI}}-(\mathrm{I} \uparrow+\mathrm{I} \downarrow)\right)$ from the relation:

$$
\tau=\mathrm{Q}_{\mathrm{S}} / \mathrm{S}_{0}
$$

The long wave radiation balance depends on the atmospheric and surface emissions and the atmospheric and surface temperatures as (Idso 1981):

$$
(\mathrm{I} \uparrow+\mathrm{I} \downarrow)=\left[0.7+5.95 \mathrm{X} 10-5 e_{\mathrm{A}} \exp \left(1500 / \mathrm{T}_{\mathrm{A}}\right)\right] \sigma \mathrm{T}_{\mathrm{A}}{ }^{4}[6]
$$

Vapor pressure deficit $(V P D)$ was calculated using the equation:

$$
V P D=e_{S}[1-H R]
$$

where $e_{\mathrm{S}}(\mathrm{kPa})$ and $H R=$ saturation vapor pressure and relative humidity.

Saturation vapor pressure is derived as follows: $e_{S}=$ $0.6108 \exp \left[17.27 \mathrm{~T}_{\mathrm{A}} /\left(\mathrm{T}_{\mathrm{A}}+237.3\right)\right]$ where $\mathrm{T}_{\mathrm{A}}\left({ }^{\circ} \mathrm{C}\right)$ is the air temperature.

Aerodynamic resistance $\left(\mathrm{s} \mathrm{m}^{-1}\right)$ was estimated by the following relationship:

$$
r_{A}=\left[\frac{1}{\left(K^{2}\right)(u)}\right] \ln \left[\frac{z_{W}-d}{z_{O}}\right] \ln \left[\frac{z_{O}-d}{(0.2)\left(z_{O}\right)}\right]
$$

where $Z_{W}=$ height at which the wind was measured (m), $d=$ level of displacement of zero, that is the height of the active surface which determines the degree of deviation of the air volume exerted by vegetation $(\mathrm{m}), K=$ constant of von Karmann, $u=$ wind speed $\left(\mathrm{m} \mathrm{s}^{-1}\right)$ and $\mathrm{Z}_{0}=$ measure of the aerodynamic surface heterogeneity, in this case, of the vegetation (m).

As part of the physiological factors, stomatal conductance $\left(g_{S}\right)$, as the inverse of stomatal resistance $\left(r_{S}=1 / g_{S}\right)$, and leaf area index (LAI, $\mathrm{m}^{2} \mathrm{~m}^{-2}$ ) were used to calculate canopy resistance $\left(\mathrm{r}_{\mathrm{C}}\right)\left(\mathrm{s} \mathrm{m}^{-1}\right)$ with the following expression:

$$
\mathrm{r}_{\mathrm{C}}=\mathrm{r}_{\mathrm{S}} / \mathrm{LAI}
$$

With the data obtained from the measured net radiation from La Joya and La Orduña sites, we estimated the atmosphere transmission. This transmission was used to estimate the net radiation $\left(\mathrm{Q}_{\mathrm{N}}\right)$ in other sites with similar climatic conditions and altitude, as it was considered that atmospheric conditions of turbidity were similar in those sites. Subsequently, data were utilized to feed Penman-Monteith model and we estimated the evapotranspiration (ETE). Isoline maps and graphs were developed for $\mathrm{Q}_{\mathrm{N}}$ and ETE. Real evapotranspiration (ETR) was calculated with the measured variables in La Joya and La Orduña sites, and Penman-Monteith model and the simplified water balance was calculated.

Construction of the isoline maps was performed using Surfer software package (version 7.0, Golden Software, Inc. Golden, $\mathrm{CO}, \mathrm{USA}$ ), which builds on points the places settled $\mathrm{Q}_{\mathrm{N}}$ and ETE (50 sites), subsequently interpolating these values using the Kriging method, therefore the maps obtained were representative of the configuration $Q_{N}$ and ETE in the study area, as this method performs interpolation with least squares of the spatial distributions.

\section{RESULTS}

Net radiation $\left(Q_{N}\right)$. Different conditions of atmospheric transmission influenced $Q_{N}$ through the year 2007 in La Orduña and La Joya, Veracruz. Figure 2 shows some typical days with high and low transmittance values. On day of year (doy) 43 (cold season), maximum $\mathrm{Q}_{\mathrm{N}}$ was $490.2 \mathrm{~W} \mathrm{~m}^{-2}$ at $11: 40 \mathrm{~h}$, average was $312.2 \mathrm{~W} \mathrm{~m}^{-2}$ and an average trans- 

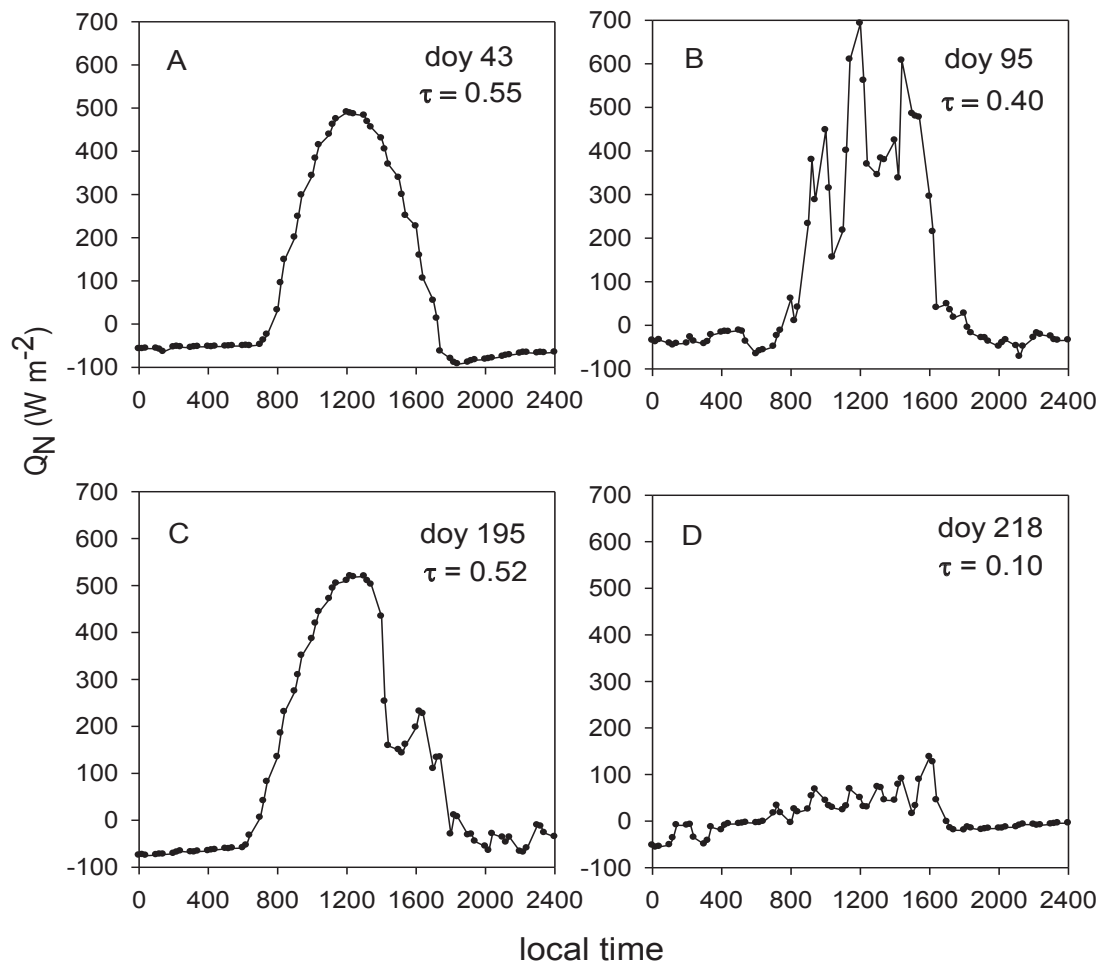

Figure 2. Net radiation patterns on days of year 43 (A), 95 (B), 195 (C) and 218 (D) with different conditions of atmospheric transmission coefficient $(\tau)$ throughout the year 2007 in La Orduña (A, B) and La Joya (C, D), Veracruz.

Patrones de radiación neta en los días del año 43 (A), 95 (B), 195 (C) y 218 (D) con diferentes condiciones del coeficiente de transmisión atmosférico $(\tau)$ a través del año 2007 en La Orduña (A, B) y La Joya (C, D), Veracruz.

mittance value was 0.55 . On doy 95 (spring) maximum $\mathrm{Q}_{\mathrm{N}}$ was $692.2 \mathrm{~W} \mathrm{~m}^{-2}$ at $11: 40 \mathrm{~h}$; the average transmittance was 0.40 and average radiation $302.2 \mathrm{~W} \mathrm{~m}^{-2}$ at La Orduña (figures $2 \mathrm{~A}, \mathrm{~B}$ ). On doy 195 , average $\mathrm{Q}_{\mathrm{N}}$ was $295 \mathrm{~W} \mathrm{~m}^{-2}$ with a transmittance of 0.52 . On day 218 the maximum $Q_{N}$ was $137.4 \mathrm{~W} \mathrm{~m}^{-2}$ at $15: 40 \mathrm{~h}$ with a transmittance of 0.10 at La Joya. Day 220 was similar to doy 195 (figures 2C, D).

Spatial distribution of the estimated net radiation. In figure 3 it is shown the distribution of the daily cumulative $Q_{N}$ for February (figure 3A), April (figure 3B), July (figure 3C) and November (figure 3D) (end of the wet-cold season, dry-hot season, rainy and end of rainy season, respectively). In general, these distributions followed the topographic pattern of the region where, at lower altitudes $(1,000$ $\mathrm{m}$ a.s.1.), radiation has high values with average values of up to $22.00 \mathrm{MJ} \mathrm{m}^{-2} \mathrm{~d}^{-1}$. $\mathrm{Q}_{\mathrm{N}}$ behavior during February is contrary to that of the other months, having an opposite radiative gradient as $\mathrm{Q}_{\mathrm{N}}$ increased with increasing altitude with relatively low values compared to the other months.

Stomatal resistance $\left(r_{S}\right)$. Minimum $\mathrm{r}_{\mathrm{s}}$ were registered in August, increasing gradually in October, November and March. In these last two months, we observed similar values in the spiny- needle-leaved species. At lower eleva- tion $\left(1,460 \mathrm{~m}\right.$ a.s.l., Xalapa) lower values of $\mathrm{r}_{\mathrm{S}}$ were registered during the four seasons, whereas at medium $(2,100$ $\mathrm{m}$ a.s.l., La Joya) and high altitude (2,900 m a.s.l., El Rosario) we found no differences (figure 4).

In August, P. patula presented the highest $\mathrm{r}_{\mathrm{S}}(1.0$ and $1.42 \mathrm{~m} \mathrm{~s}^{-1}$ in Xalapa and El Rosario, respectively). In October, $\mathrm{r}_{\mathrm{S}}$ varied among species and sites. In the lower site, $\mathrm{r}_{\mathrm{S}}$ varied between 1.5 and $2.5 \mathrm{~m} \mathrm{~s}^{-1}$, followed by the highest values at medium altitude. At higher altitude, $\mathrm{r}_{\mathrm{s}}$ varied between 2.2 and $2.8 \mathrm{~m} \mathrm{~s}^{-1}$. Stomatal resistance for November and March were similar and the highest for all the seasons. Values obtained during November were $2.5-4.1 \mathrm{~m} \mathrm{~s}^{-1}$, and for March were 2.5 - $3.7 \mathrm{~m} \mathrm{~s}^{-1}$ (figure 4).

Stomatal resistance values of broadleaf trees presented enormous variations among species and seasons. In general species at lower elevation (1,460 m a.s.l., Xalapa) had the highest $r_{s}$, except in November, followed by species from mid-altitude, whereas values of the species from higher elevations were the lowest, except during the rainy season.

The highest $r_{S}$ were found in Xalapa (lowest altitude) in August. All species had high $\mathrm{r}_{\mathrm{S}}\left(0.60-1.0 \mathrm{~m} \mathrm{~s}^{-1}\right)$. Platanus mexicana had the lowest average value $\left(0.60 \mathrm{~m} \mathrm{~s}^{-1}\right)$; followed by $L$. styraciflua and $Q$. xalapensis averages of ca. $0.80 \mathrm{~m} \mathrm{~s}^{-1}, Q$. germana had the highest value $(1.0 \mathrm{~m}$ $\left.\mathrm{s}^{-1}\right)$. At higher altitude, Q. microphylla had $\mathrm{r}_{\mathrm{s}}$ of $0.85 \mathrm{~m} \mathrm{~s}^{-1}$. 

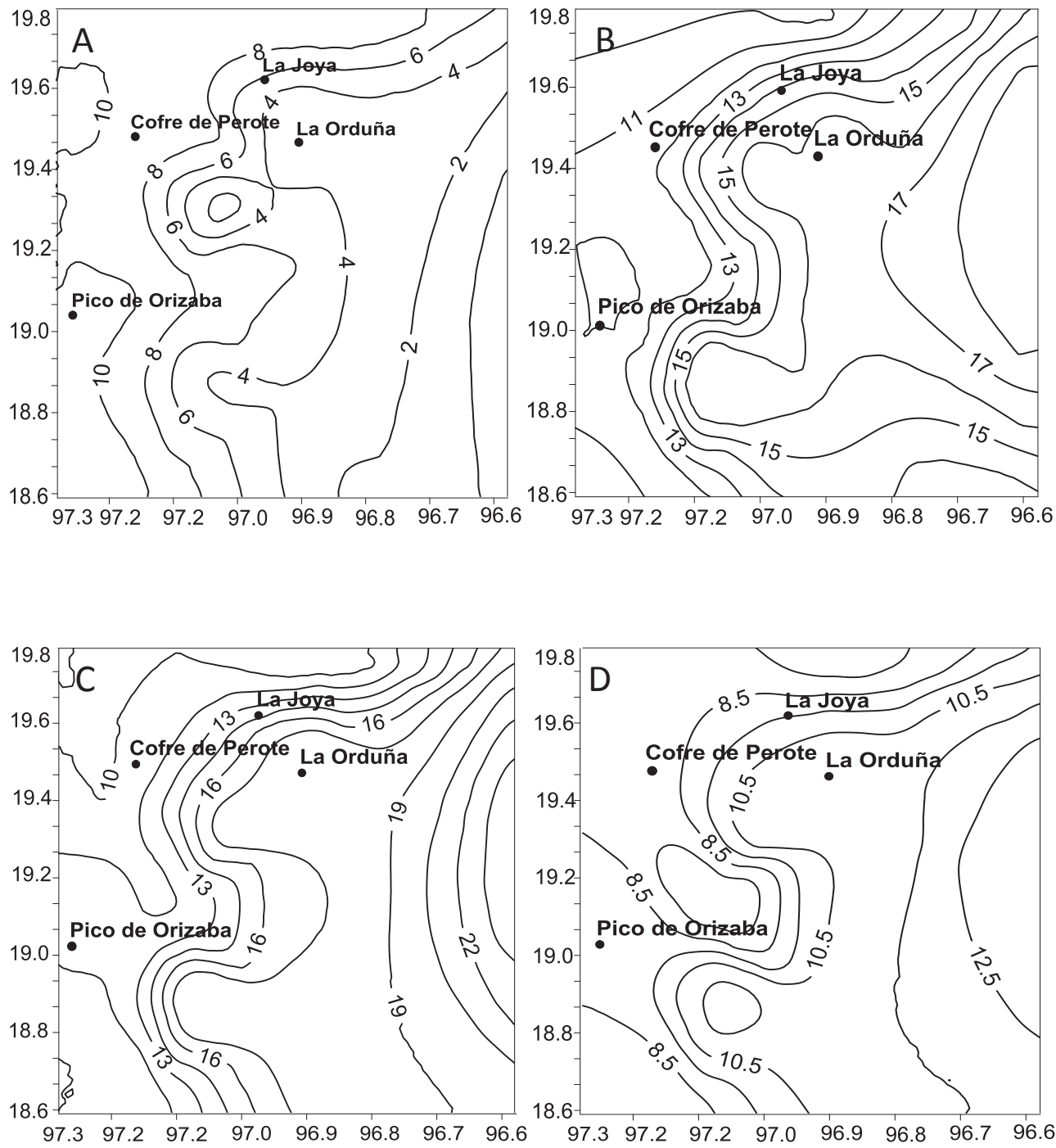

Figure 3. Spatial distribution of the calculated daily cumulative net radiation (MW m ${ }^{-2}$ ) during February (A), April (B), July (C) and November (D) 2007, in the study region.

Distribución espacial de la radiación neta calculada acumulada $\left(\mathrm{MJ} \mathrm{m}^{-2} \mathrm{~s}^{-1}, \mathrm{~b}\right)$ durante febrero (A), abril (B), julio (C) y noviembre (D) 2007, en la región de estudio.

In October, higher $\mathrm{r}_{\mathrm{s}}$ corresponded to Platanus mexicana, L. styraciflua and $Q$. xalapensis $\left(\mathrm{r}_{\mathrm{s}}\right.$ between 0.60 and $0.70 \mathrm{~m} \mathrm{~s}^{-1}$ ), and $Q$. germana presented the highest value during this season. At mid-altitude, all species exhibited similar values $\left(0.75\right.$ to $\left.0.82 \mathrm{~m} \mathrm{~s}^{-1}\right)$. At the highest altitude, Q. microphylla showed the lowest $\mathrm{r}_{\mathrm{S}}\left(0.58 \mathrm{~m} \mathrm{~s}^{-1}\right)$.

The lowest $r_{S}$ of the four seasons were taken in November, finding the lowest values in Xalapa (lowest altitude). Liquidambar styraciflua and $Q$. xalapensis exhibited similar averages and lowest values $\left(0.41 \mathrm{~m} \mathrm{~s}^{-1}\right)$, whereas Platanus mexicana and Q. germana had higher values. At mid-altitude, all species exhibited similar values $\left(0.65 \mathrm{~m} \mathrm{~s}^{-1}\right)$; the species from higher altitude showed a value of $0.58 \mathrm{~m} \mathrm{~s}^{-1}$. In March, at low elevation, Platanus mexicana and $L$. styraciflua recorded values of $c a .0 .58 \mathrm{~m} \mathrm{~s}^{-1}$, whereas $Q$. xalapensis and Q. germana exhibited higher $\mathrm{r}_{\mathrm{S}}$ at mid-altitude. Alnus acuminata had the lowest value $\left(0.60 \mathrm{~m} \mathrm{~s}^{-1}\right)$, whereas $Q$. laurina and $Q$. crassifolia had values between 0.90 and $1.05 \mathrm{~m} \mathrm{~s}^{-1}$. At higher altitude, Q. microphylla had $0.57 \mathrm{~s} \mathrm{~m}^{-1}$ (figure 5).

Canopy and aerodynamic resistance. In the pine forest for all seasons, canopy resistance $\left(\mathrm{r}_{\mathrm{C}}\right)$ was lower than the aerodynamic resistance $\left(\mathrm{r}_{\mathrm{A}}\right)$. Maximum $\mathrm{r}_{\mathrm{C}}$ occurred in the transition from dry to wet season $\left(0.17 \mathrm{~m} \mathrm{~s}^{-1}\right)$ and minimum $\left(0.04 \mathrm{~m} \mathrm{~s}^{-1}\right)$ was registered in June, in the wet season. Concerning $\mathrm{r}_{\mathrm{A}}$, maximum $\mathrm{r}_{\mathrm{A}}$ was $9.13 \mathrm{~m} \mathrm{~s}^{-1}$ in November, and minimum $\mathrm{r}_{\mathrm{A}}$ was $6 \mathrm{~m} \mathrm{~s}^{-1}$ in the dry season (table 1). Canopy resistance was lower in the wet season. The $\mathrm{r}_{\mathrm{A}}$ response tended to increase from wet to dry season. 


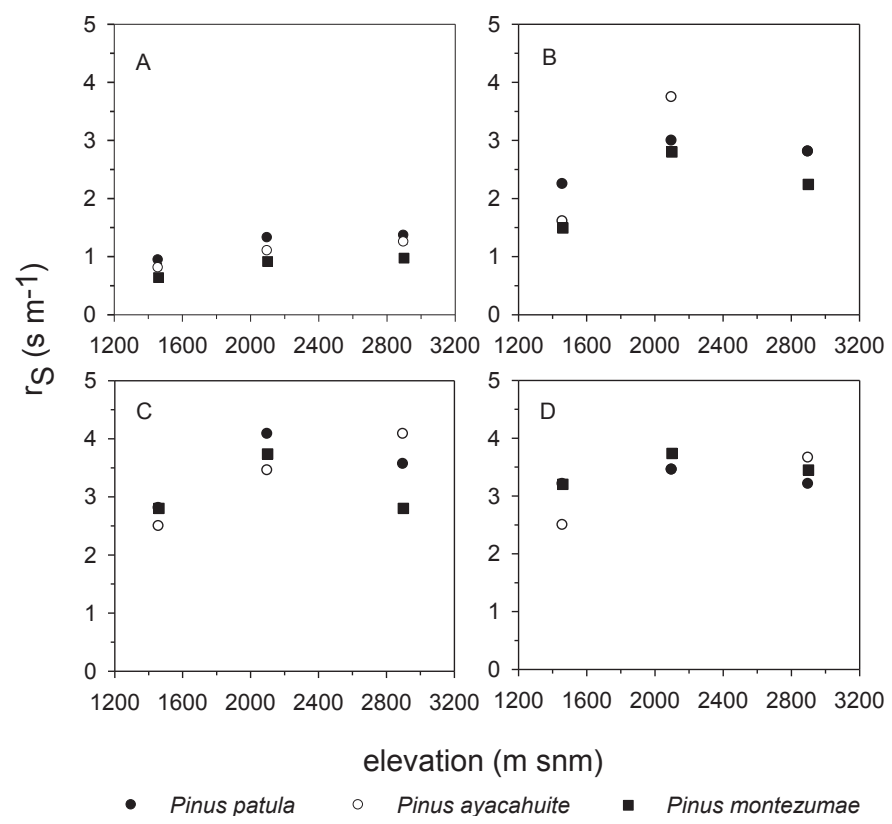

Figure 4. Stomatal resistance $\left(r_{\mathrm{S}}\right)$ in pine forests at different altitudes in the mountain central region of Veracruz, 1,460 m a.s.1. (Xalapa), 2,100 m a.s.l. (La Joya) and 2,900 m a.s.l. (El Rosario) in August (A), October (B), November (C) and March (D). Symbols represent the averages (in all cases the standard error is smaller than the symbols and are not displayed), $\mathrm{n}=41$.

Resistencia estomática $\left(\mathrm{r}_{\mathrm{s}}\right)$ en un bosque de pinos a diferentes altitudes en la región central montañosa de Veracruz, $1.460 \mathrm{~m}$ snm (Xalapa), $2.100 \mathrm{~m} \mathrm{snm}$ (La Joya) y $2.900 \mathrm{~m}$ snm (El Rosario) en agosto (A), octubre (B), noviembre (C) and marzo (D). Los símbolos representan los valores promedio (en todos los casos el error estándar es más pequeño los símbolos y no se muestran), n = 41.

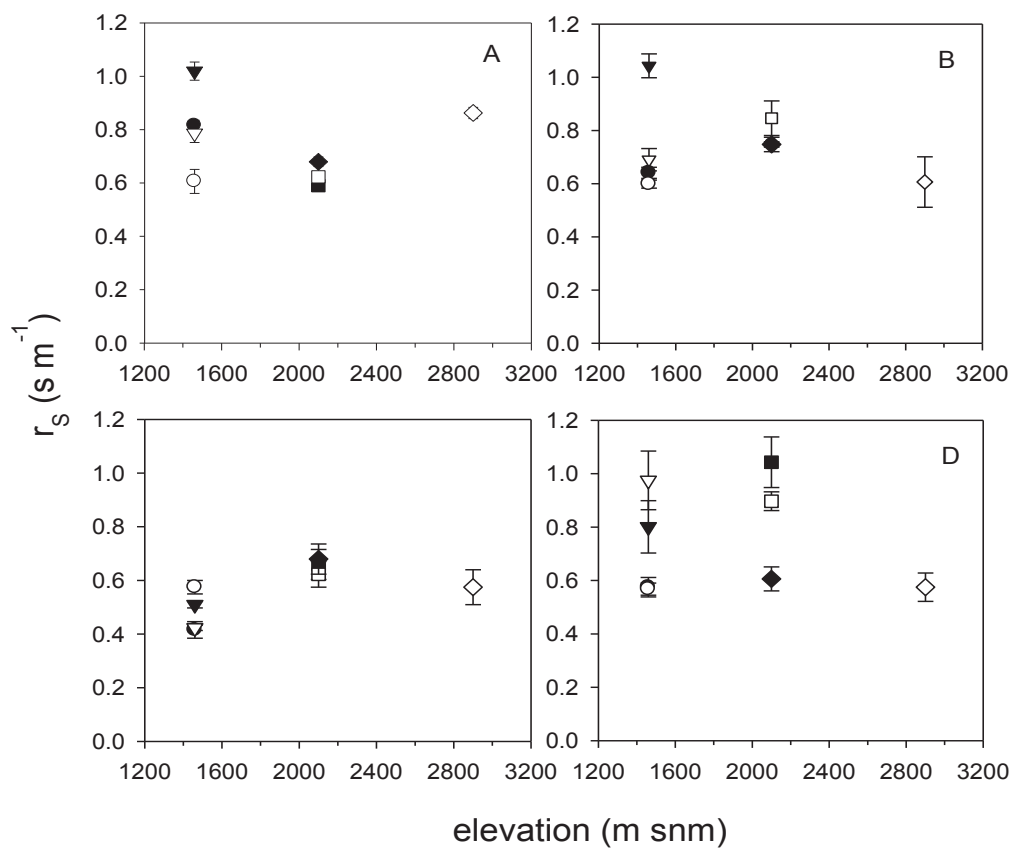

Figure 5. Stomatal resistance $\left(r_{\mathrm{S}}\right)$ of the species from the cloud forest, the pine-oak and pine forests at three different altitudes $(1,460$ $\mathrm{m}$ a.s.1., cloud forest; 2,100 m a.s.1., pine-oak forest; 2,900 m a.s.1., pine) in August (A), October (B), November (C) and March (D) in the mountain central region of Veracruz. Symbols represent the averages and standard error are presented in bars (in some cases the standard error is smaller than the symbols and are not displayed), $\mathrm{n}=36$.

Resistencia estomática $\left(\mathrm{r}_{\mathrm{S}}\right)$ de especies del bosque nuboso, de bosque pino-encino y bosque de pino en tres diferentes altitudes $(1.460 \mathrm{~m}$ snm, bosque nuboso; $2.100 \mathrm{~m} \mathrm{snm}$, bosque pino-encino; $2.900 \mathrm{~m} \mathrm{snm}$, bosque de pino) en agosto (A), octubre (B), noviembre (C) y marzo (D) en la región central montañoso de Veracruz. Los símbolos representan los valores promedio (en todos los casos el error estándar es más pequeño que los símbolos y no se muestran), $\mathrm{n}=36$. 
Table 1. Leaf area index (LAI), canopy $\left(\mathrm{r}_{\mathrm{C}}\right)$ and aerodynamic $\left(\mathrm{r}_{\mathrm{A}}\right)$ resistance averages from different ecosystems in the mountain central region of Veracruz: 1) Pine forest (P. patula, P. ayacahuite and P. montezumae), measures taken from 8:00-18:00 h (local time); 2) cloud forest (Q. germana, Q. xalapensis, Platanus mexicana, L. styraciflua), measures taken from 9:00-17:00 h; 3) Grassland (rye grass, Lolium multiflorum), measures taken from 8:00-18:00 h, and 4) sugarcane crop (Saccharum officinarum), measures taken from 9:00-17:00 h.

Índice de área foliar (LAI), promedios de la resistencia del dosel $\left(\mathrm{r}_{\mathrm{C}}\right)$ y aerodinámica $\left(\mathrm{r}_{\mathrm{A}}\right)$ resistance de diferentes ecosistemas en la región central montañosa de Veracruz: 1) Bosque de pinos (P. patula, P. ayacahuite and P. montezumae), mediciones tomadas de 8:00 a 18:00 h (hora local); 2) Bosque nuboso (Q. germana, Q. xalapensis, P. mexicana, L. styraciflua), mediciones tomadas de 9:00 a 17:00 h; 3) Pastizal, Lolium multiflorum), mediciones de 8:00 a 18:00 h, y 4) Caña de azúcar (Saccharum officinarum), mediciones de 9:00 a17:00 h.

\begin{tabular}{|c|c|c|c|c|}
\hline Ecosystem & Month & LAI $\left(\mathrm{m}^{2} \mathrm{~m}^{-2}\right)$ & $\mathrm{r}_{\mathrm{C}}\left(\mathrm{s} \mathrm{m}^{-1}\right)$ & $\mathrm{r}_{\mathrm{A}}\left(\mathrm{s} \mathrm{m}^{-1}\right)$ \\
\hline \multirow{5}{*}{ Pine forest } & June & 6.00 & 0.04 & 9.02 \\
\hline & August & 5.47 & 0.06 & 7.40 \\
\hline & October & 5.30 & 0.14 & 9.03 \\
\hline & November & 5.10 & 0.17 & 9.13 \\
\hline & March & 4.70 & 0.10 & 6.00 \\
\hline \multirow{3}{*}{ Cloud forest } & February & 2.80 & 162.50 & 74.40 \\
\hline & April & 1.56 & 37.60 & 106.50 \\
\hline & July & 1.86 & 85.20 & 6.30 \\
\hline \multirow{5}{*}{ Rye grass } & June & 1.20 & 0.60 & 20.70 \\
\hline & August & 1.20 & 0.60 & 18.00 \\
\hline & October & 1.20 & 0.70 & 26.30 \\
\hline & November & 1.20 & 0.60 & 25.00 \\
\hline & March & 1.20 & 0.80 & 29.20 \\
\hline \multirow{3}{*}{ Sugarcane } & June & 0.87 & 425.80 & 29.90 \\
\hline & February & 5.26 & 37.60 & 106.50 \\
\hline & April & 0.70 & 429.60 & 39.10 \\
\hline
\end{tabular}

In the cloud forest, $r_{C}$ and $r_{A}$ did not follow a specific pattern. Canopy resistance was much higher in the cloud forest than in the pine forest (table 1). The highest $\mathrm{r}_{\mathrm{C}}$ was registered in February and the lowest in April. The highest and lowest LAI were also recorded in those months, coinciding with the storage of leaf production during the growing season, which began at the beginning of the wet season, hence in the dry season (December to April established -May) trees let their leaves fall and thus LAI is reduced (table 1).

Table 1 shows $r_{C}$ and $r_{A}$ averages from two main crops in the area (rye grass and sugarcane). The $\mathrm{r}_{\mathrm{C}}$ in sugarcane was considerably higher than in rye grass (L. multiflorum). The $r_{A}$ was similar except in February. These differences were probably because of differences of LAI. Canopy resistance and $r_{A}$ in rye grass were lower than those observed in the pine forest; however, in sugarcane were higher than those recorded in the cloud forest.

Estimated evapotranspiration. Distributions of the estimated evapotranspiration (ETE) were similar to those of $\mathrm{Q}_{\mathrm{N}}$, following the topographic pattern where the highest values are located at lower altitudes (figure 6); however, differences in land use of the different vegetation types also determined these distributions. ETE distribution was opposed in July; in this month evapotranspiration increased with altitude. This was probably because of differences in cloudiness, characteristic of this rainy month. As for water balance, we considered rainfall $(P p)$ and real evapotranspiration (ETR) in La Joya and La Orduña, finding differences between sites (figure 7).

\section{DISCUSSION}

Stomatal control in forests and crops. Leaf area index was higher in forests than in crops. LAI importance and species composition has been related to photosynthesis in different forest types (Bonan 1993). This was possibly because of a larger number and volume of the forests' foliar coverage. Probably, increase in LAI in the forests during the wet season was due to the increased foliage cover as a result of favorable microclimate conditions during this season. Changes in humidity, reserve water amount or water stress are reflected in LAI (Rey 1999). In forest ecosystems, stomatal control is highly important in regulating microclimate and controlling transpiration (Jones 1992), and regulating VPD and temperature (Esperón-Rodríguez and Barradas 2014ab). Thus, stomatal behavior is a key 

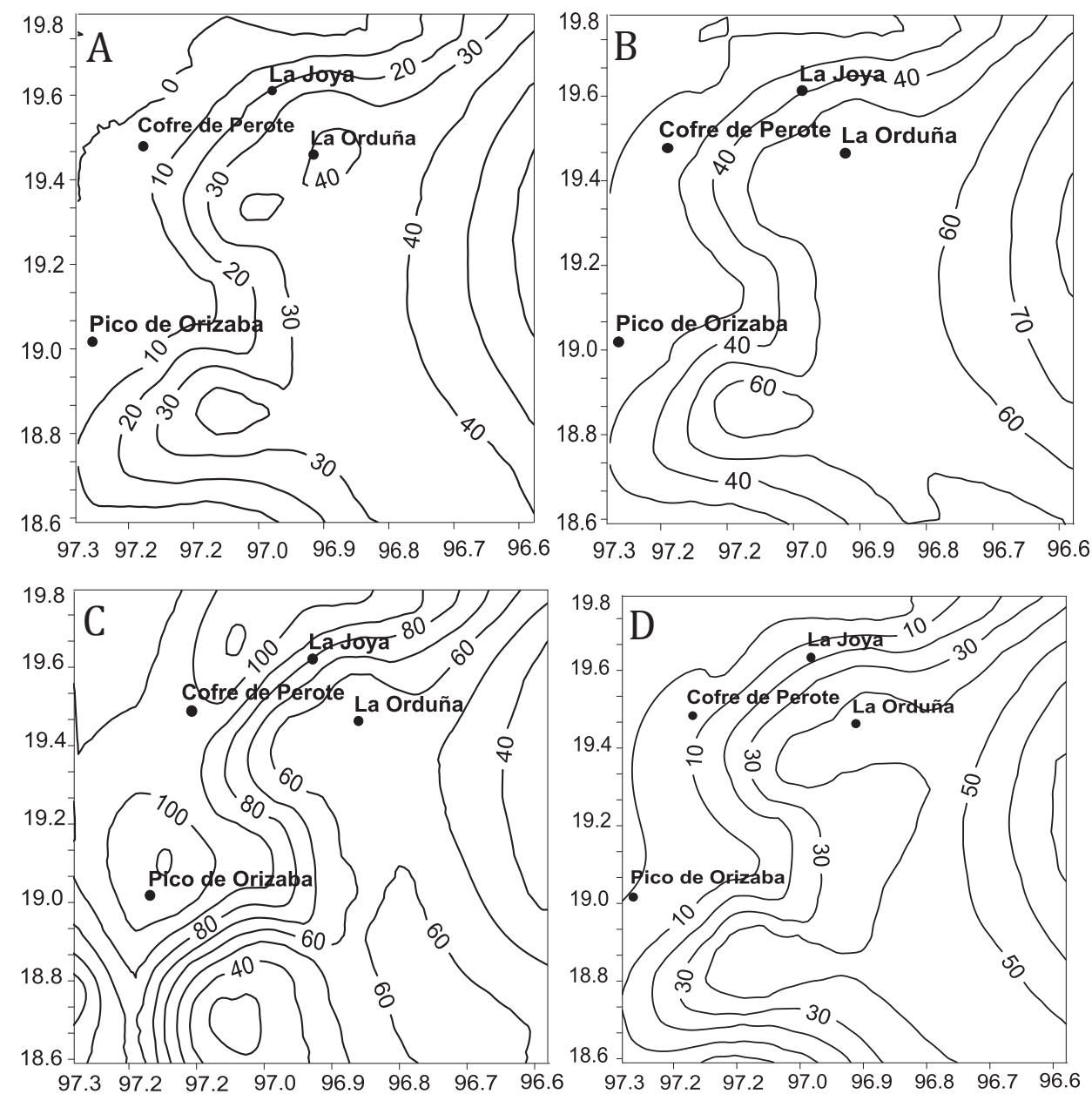

Figure 6. Spatial distribution of estimated daily cumulative of evapotranspiration (mm) during February (A), April (B), July (C) and November (D) in the study region.

Distribución espacial de la evapotranspiración estimada acumulada ( $\mathrm{mm}$ ) durante febrero (A), abril (B), julio (C) and noviembre (D) en la región de estudio.

response of plants to climate, as it controls transpiration (water status) and $\mathrm{CO}_{2}$ assimilation, and plays an important role in photosynthesis and plant productivity (Jones 1992). Regarding grassland, which was induced primarily for livestock, the area kept its cover and density constant in all seasons, where environmental conditions were not involved in the vegetation dynamics, keeping LAI unaffected (table 1).

Concerning $r_{s}$, its response tended to decrease in forests and increase in crops, being this behavior more evident in the wet season. Microclimate conditions in the forest, and higher LAI, probably favored the $\mathrm{r}_{\mathrm{S}}$ reduction facilitating transpiration. Previous studies noted this $r_{S}$ relation between forests and crops (Kramer and Kozlowski 1998), wherein stomatal control varies depending on plant species and on environmental variables such as VPD, air temperature and wind speed (Larcher 2003).

Variations in $r_{C}$ are a reflection of the stomatal function; hence, its relationship with LAI appears as important. Ca- nopy resistance is an integrated value of stomatal resistance (Sommer et al. 2002), where it can be affected by LAI (Frank 2003). Probably $r_{C}$ in the pine and cloud forests was lower during the wet season for the microclimate and high LAI. In the case of the crop and the grassland, $\mathrm{r}_{\mathrm{C}}$ was calculated using a single value of LAI, as a result of the constant grass volume; thus its variation was only a $r_{s}$ function for all seasons. This indicates that the variation of stomatal control in the grassland was essentially from the canopy. Although the $r_{S}$ response was inherent to species and site characteristics, VPD might have affected the $r_{S}$ variation in the forests and grassland, where the conductivity of the canopy responded significantly to VPD (Kelliher et al. 1993, Sommer et al. 2002).

As for $\mathrm{r}_{\wedge}$, it was lower in forests than in crops. This variable is a function of several variables such as wind speed, vegetation height and cover, and LAI, among others, which determines the degree of resistance to water vapor diffusion opposing surfaces and roughness-canopy rough- 


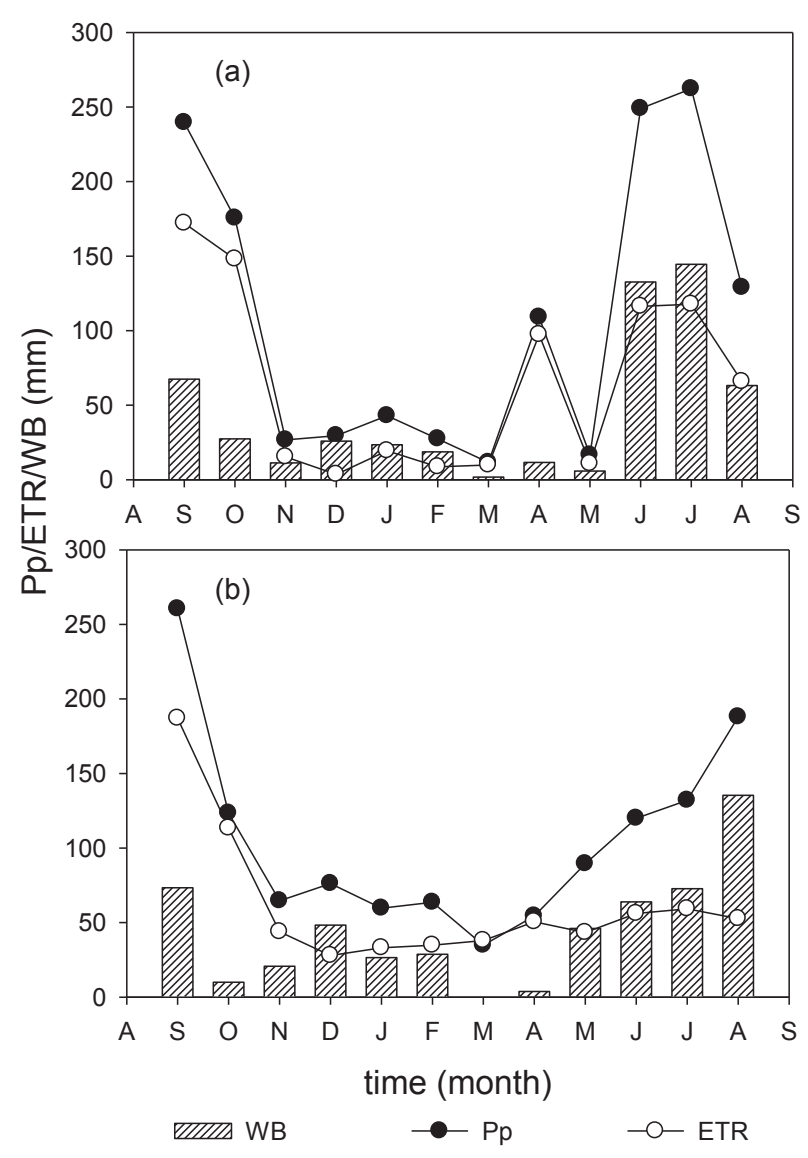

Figure 7. Water balance (WB) as a function of rainfall $(\mathrm{Pp})$ and real evapotranspiration (ETR) in La Joya (A) and La Orduña (B), Veracruz, Mexico.

Balance hídrico (WB) como una función de la precipitación $(P p)$ y la evapotranspiración real (ETR) en La Joya (A) y La Orduña (B), Veracruz, México.

ness (Kelliher et al. 1993). Thus, due to the contrasting biophysical and physiological characteristics between forests and crops, there were differences in the estimated $r_{A}$ of each system. Probably the low vegetation cover in the crops, as well as their height and LAI, increased $r_{A}$; whereas in the forests, the increased LAI and the vegetation height resulted in lower $\mathrm{r}_{\mathrm{A}}$ (Kelliher et al. 1993).

Estimated evapotranspiration. After analyzing the ETE distribution, it is clear that $Q_{N}$ plays an important role in the evapotranspiration process. VPD was low most of the year, and we found that the fog frequency had a minimal effect. Our results suggest that ETE was mainly affected by $\mathrm{Q}_{\mathrm{N}}$ and $\mathrm{r}_{\mathrm{C}}$.

Another factor affecting evapotranspiration (ET) is the leaf size. Leaf size in pine forests is usually low, but in the cloud and pine-oak forests it can be high, being common to find larger sizes in lower strata (Richards 1964). This is highly important because most solar energy received in the leaf is used in ET (Monteith 1977). The high sensitivity of ET to changes in $Q_{N}$ is evident when analyzing the PenmanMonteith model: when $\mathrm{r}_{\mathrm{A}}$ is large $\left(\mathrm{r}_{\mathrm{A}}\right.$ is superior in larger leaves, Grace et al. 1980), the coefficient $\rho C p\left(V P D / \mathrm{r}_{\mathrm{A}}\right)$ represents only a fraction of the numerator (equation 2), which depends primarily on the $\mathrm{Q}_{\mathrm{N}}$. Hence, most of the evaporated water comes from the dominant species from the upper canopy. Moreover, it is also expected that $\mathrm{Q}_{\mathrm{N}}$ transferred to the soil would be small, and thus the amount of water evaporated from the soil should be minimal (Barradas 1991).

Besides, the energy generated by ET forms part of the energy balance of the system, where the change of land use in natural systems causes a redistribution of $Q_{N}$. Such is the case of drastic changes from forest to grassland evidencing regional climatic changes (Barradas et al. 2010).

Water balance. These locations present the typical pattern of the region with wet and dry seasons. When contrasting ETR and rainfall we found that although water loss by evapotranspiration is high, there was a net gain of water in both locations $(526.5 \mathrm{~mm}$ in La Joya and $533.8 \mathrm{~mm}$ in La Orduña) from September 2006 to August 2007. In the dry season (October to May), the gain of water was very low, zero or negative, as it happened in March at the two sites. It is clear that March and April were months with the least amount of water being this of -3.1 and $1.74 \mathrm{~mm}$, and 3.8 and $11.6 \mathrm{~mm}$ (March and April) in La Orduña and La Joya, respectively. Annual precipitation at both sites was $1,266.4 \mathrm{~mm}$ in $\mathrm{La}$ Orduña and 1,318.9 $\mathrm{mm}$ in La Joya. These values contrast with those found in forests of $P$. caribaea in three locations with 2,054 $\mathrm{mm}$ (Waterloo et al. 1999), and although this precipitation was high, evapotranspiration was similar. With this information we can get a better approximation of the potential distribution of the available water to implement or propose strategies for sustainable exploitation in the region.

Our results show the importance of forest in the evapotranspiration process. Some of the studied species as L. styraciflua and Platanus mexicana have high transpirations rates (Esperón-Rodríguez and Barradas 2014b, 2015), and because plants through transpiration decrease air temperature, species with high transpiration can help mitigate the meso-climate change presented in the region (Barradas et al. 2010), promoting better environmental thermal comfort conditions. Another factor favored by forests is soil conservation, which is also important for transpiration and the evapotranspiration process. During these processes, good soil conditions can ensure that most water of the substrate is absorbed by the roots, depending on the permeability and extent of the same, hence the absorbed water is efficiently conducted through the vascular system to all tissues and organs to perform the plant's vital functions. The forests in the central mountain region of Veracruz can provide ecosystem services favoring evapotranspiration and regulating water balance, but the lack of information on the magnitude and value of these services has hindered the recognition and understanding of these forests. 
Evapotranspiration plays an important role in water services provided by forests, being the only irrecoverable factor in a water system, because runoff and infiltration can be stored superficially or underground. Although these results show that the region does not exhibit strong water deficits, there may be a water shortage for human activities during the dry season, therefore it is necessary to implement an effective management plan to avoid this problem and to propose strategies for sustainable exploitation of this resource. Under the same terms, these results can also be used to implement more accurate policies for the forest environmental services payment in the mountainous central region of the state of Veracruz.

\section{ACKNOWLEDGMENTS}

We thank Martín Bonifacio for the provided technical assistance. Also we thank two anonymous reviewers for their critical observations for the improving of this work. This work was supported by CONACyT-SEMARNAT with grant No. 2004-C01-332.

\section{REFERENCES}

Barradas VL. 1991. Radiation regime in a tropical dry deciduous forest in western Mexico. Theoretical and Applied Climatology 44: 57-64.

Barradas VL. 2000. Modificaciones del microclima con énfasis en la conservación y la restauración ecológica. Boletín de la Sociedad Botánica de México 65: 83-88.

Barradas VL, J Cervantes-Pérez, R Ramos-Palacios, C PuchetAnyul, P Vázquez-Rodríguez, R Granados-Ramirez. 2010. Meso-scale climate change in the central mountain region of Veracruz State, Mexico. In Bruijnzeel LA, FN Scatena, LS Hamilton eds. Tropical Montane Cloud Forests. Science for Conservation and Management. Cambridge, UK. Cambridge University Press. p. 549-556.

Barradas VL, LM Tapia-Vargas, J Cervantes-Pérez. 2011. Consecuencias del cambio climático en la ecofisiología vegetal de un bosque templado en Veracruz. Revista Mexicana de Ciencias Agrícolas 21: 183-194.

Bonan GB. 1993. Importance of leaf area index and forest type when estimating photosynthesis in boreal forests. Remote Sensing of Environment 43: 303-314.

Bosveld FC, W Bouten. 2001. Evaluation of transpiration models with observations over a Douglas-fir forest. Agricultural and Forest Meteorology 108: 247-264.

Esperón-Rodríguez M, VL Barradas. 2014a. Ecophysiological vulnerability to climate change: water stress responses in four tree species from the central mountain region of Veracruz, Mexico. Regional Environmental Change 15(1). doi 10.1007/s10113-014-0624-x.

Esperón-Rodríguez M, VL Barradas. 2014b. Potential vulnerabi- lity to climate change of four tree species from the central mountain region of Veracruz, Mexico. Climate Research 60: 163-174 DOI: 10.3354/cr01231

Esperón-Rodríguez M, VL Barradas. 2015. Comparing environmental vulnerability in the montane cloud forest of eastern Mexico: A vulnerability index. Ecological Indicators 52: 300-310 http://dx.doi.org/10.1016/j.ecolind.2014.12.019

Frank AB. 2003. Evapotranspiration form northern semiarid grasslands. Agronomy Journal 95: 1504-1509.

Grace J, FE Fasehun, M Dixon. 1980. Boundary layer conductance of the leaves of some tropical timber trees. Plant, Cell and Environment 3: 443-450.

Idso SB. 1981. A set of equations for full spectrum and 8- to $14-\mu$ and 10 - to $\mu \mathrm{m}$ thermal radiation from cloudless skies. Water Resources Research 17: 295-304.

Jones HG. 1992. Plants and microclimate. Cambridge, UK. Cambridge University Press. 428 p.

Kramer PJ, TT Kozlowski. 1998. Physiology of woody plants. London, UK. Academic Press. 464 p.

Kelliher FM, R Leuning, ED Schulze. 1993. Evaporation and canopy characteristics of coniferous forest and grasslands. Oecologia 95: 153-163.

Larcher W. 2003. Physiology plant ecology. 4th ed. Berlin, Germany. Springer. $513 \mathrm{p}$.

Meza PE, D Geissert. 2003. Estructura, agregación y porosidad en suelos forestales y cultivados de origen volcánico del Cofre de Perote, Veracruz, México. Foresta Veracruzana 5: 57-60.

Monteith JL. 1977. Climate. In Alvim P de T, TT Koslowski eds. Ecophysiology of tropical crops. London, UK. Academic Press. p. 1-27.

Rey JM. 1999. Modelling potential evapotranspiration of potential vegetation. Ecological Modelling. 123: 14-159.

Richards PW. 1964. The tropical rain forests. London, UK. Cambridge University Press. $450 \mathrm{p}$.

Runyon J, R Waring, S Goward, J Welles. 1994. Environmental limits on net primary production and light-use efficiency across the Oregon transect. Ecological Applications 4: 226-237.

Sommer R, TD de Abreu, V Konrad, A Carioca de Araujo, H Fölster, PLG Vlek. 2002. Transpiration and canopy conductance of secondary vegetation in the eastern Amazon. Agricultural and Forest Meteorology 112: 103-121.

Torres R, FA Squeo, C Jorquera, E Aguirre, Jr Ehleringer. 2002. Evaluación de la capacidad estacional de utilizar eventos de precipitación en tres especies de arbustos nativos con distintos sistemas radiculares. Revista Chilena de Historia Natural 75: 737-749.

Waterloo MJ, LA Bruijnzeel, HF Vugts. 1999. Evaporation from Pinus caribaea plantations on former grassland soils under maritime tropical conditions. Water Resources Research 35: 2133-2144.

Williams M, Y Malhi, A Nobre, E Rastetter, J Grace, M Pereira. 1998. Seasonal variation in net carbon exchange and evapotranspiration in Brazilian rain forest: a modelling analysis. Plant Cell and Environment 21: 953-968. 
